Editorial

\title{
Peacebuilding in the Age of New Media
}

\author{
Vladimir Bratic \\ Department of Communication Studies, Hollins University, Institution, Roanoke, VA 24020, USA; \\ E-Mail:vbratic@hollins.edu
}

Submitted: 23 December 2015 |Published: 18 February 2016

\begin{abstract}
This editorial provides the historical context for the current state of peacebuilding media and introduces the articles featured in the issue.
\end{abstract}

\author{
Keywords \\ conflict; Internet; mass media; new media; peacebuilding; social media; traditional media, war
}

Issue

This article is part of the issue "Peacebuilding in the Age of New Media", edited by Vladimir Bratic (Hollins University, USA).

(C) 2016 by the author; licensee Cogitatio (Lisbon, Portugal). This article is licensed under a Creative Commons Attribution 4.0 International License (CC BY).

Media did not become an integral part of the formal peacebuilding until the end of the Cold War when specialized, non-governmental and intergovernmental agencies formalized the practice of peacebuilding and media technologies improved to allow nonprofessionals to make and distribute their own media. Therefore, the practice of using media for peacebuilding emerged in the last decade of the $20^{\text {th }}$ century when peace organizations formally began utilizing media to advance their goals in places of violent conflict.

Academic studies were slow to address this practice. There were only a handful of studies at the turn of the century explicitly studying peace and media, most of them were written by practitioners (Hieber, 2001; Howard, Rolt, van de Veen, \& Verhoeven, 2003; Lehmann, 1999). Peace and media were not studied under the same umbrella until the very end of the $20^{\text {th }}$ century because peace studies traditionally resided in political science while media studies originated in sociology. It took a few interdisciplinary efforts to recognize the distinctive practice (Price \& Thompson, 2002; Wolfsfeld, 2004). At that time, a number of different media applications in peacebuilding emerged as distinctive areas of study. The role of journalism and journalists in conflict was the most prominent area of research studied mainly by political science and journalism scholars (Kempf, 2008). Less academic and more practice-driven attempts were made to recognize that other media formats (i.e. entertainment and marketing) could also make an impact on peace (Radio Netherlands, 2004; Search for Common Ground [SFCG], 2002). Similarly, legal media scholars brought up the argument that media laws and regulatory environment are crucial ingredients of a prosperous and peaceful society (Price \& Krug, 2002).

Over the last five years the discourse in the field has shifted away from the traditional media and formal peacebuilding practice. The ever-improving technologies introduced new media channels (mobile phones, the Internet) and new media practices (new media and social media). Academic research and policy moved towards examining new ways technology can enhance democratization and social activism. Some initial results confirmed the ability of new media to inform, involve, and mobilize citizens and enhanced the ability of peacebuilding agents to achieve their goals and improve security in Africa, the Middle East, and Asia (Livingston, 2011; Stauffacher, Weekes, Gasser, Maclay \& Best, 2011). But conflict areas continue to be dominated by the influence of old, traditional media and technology which continue to be used by people for both good and bad purposes. Propaganda and attacks on journalists and free speech have not been eliminated because of the new technology and social networks.

This issue is an attempt to recognize the new questions that both practice and academia need to consider 
in the future. This issue aims to explore the innovative use of new media technologies both theoretically, as is the case in the first article of issue, as well as application of social media in violent conflict in the next four articles of the issue. At the same time, new questions have emerged in reaction to the recognized practices in peace journalism which is the subject of the last two articles of the issue.

To begin, Wolfang Sützl's "Elicitive Conflict Transformation and New Media: In Search for a Common Ground" examines the role that social media can play in communicative processes in light of Conflict Transformation Theory. The author emphasizes the absence of media theory in conflict resolution theories and draws on the common ground of both realms to conclude that social media can play an effective role in peace-building.

The next four articles describe the application of social media in practice. Yifat Mor, Yiftach Ron and Ifat Maoz's article "'Likes' for Peace: Can Facebook Promote Dialogue in the Israeli-Palestinian Conflict?" analyzes the discourse of one Facebook group among Palestinians and Israeli-Jews. Authors find out that moderate voices and peace-oriented posts by Palestinians were more likely to elicit acceptance and sympathy from Israeli-Jews.

In "Fields and Facebook: Ta'ayush's Grassroots Activism and Archiving the Peace that Will Have Come in Israel/Palestine" Jon Simons argues that the work of the activist group Ta'ayush might be considered a failure based on the traditional metrics in the scholarship of social movement and peacebuilding theory. Yet, the value of the group's online activism, he argues, is in documenting and archiving the work of activists in confronting the Occupation.

Walid Al-Saqaf explains how new media technologies can be used to circumvent state censorship of an authoritarian state in "Internet Censorship Circumvention Tools: Escaping the Control of the Syrian Regime". The author provides empirical evidence that new media can effectively bypass censorship and enable access to blocked websites, demonstrating the potential of such tools to promote freedom of expression.

"EU Armed Forces' Use of Social Media in Areas of Deployment" by Maria Hellman, Eva-Karin Olsson and Charlotte Wagnsson examines the perceptions of social media by the military forces of European states. The authors conclude that social media is seen simultaneously as a combination of opportunities to advance their communication and marketing as well as potential areas of risk.

The last two articles of the issue are the new readings on peace journalism; in "Building Peace through Journalism in the Social/Alternate Media" Rukhsana Aslam describes the changes in reporting of conflict in the time of social media networks. The author considers existing paradigms of journalism in conflict and proposes a more fluid journalism model; one based on work of synergy among journalists, academics and peace workers, emphasizing more direct engagement in conflict resolution.

In "Awareness towards Peace Journalism among Foreign Correspondents in Africa" Ylva Rodny-Gumede interviews journalists from multiple global news organizations based in Johannesburg, South Africa, and examines their awareness and attitudes toward peace journalism practice. The author finds a lack of confidence in the model yet a strong preference and established practice of many of its tenets.

Therefore, at this juncture in research it is necessary to ground the new results about new technologies in what was previously confirmed about traditional media. In the case of this particular issue, authors examine the impact of new media and technology in light of what we already know to be good practices. At this time when new media and social networks draw most of the attention of researchers and policy makers, we must understand the historical context of the practice, remain comparative in the study of regional applications and mindful of the previous lessons from not so distant cousins-old, traditional media and formal peacebuilding practice.

\section{Conflict of Interests}

The author declares no conflict of interests.

\section{References}

Hieber, L. (2001). Lifeline media: Reaching populations in crisis. A guide to developing media projects in conflict situations. Geneva: Media Action International.

Howard, R. Rolt, F. van de Veen, \& H. Verhoeven. J. (Ed.) (2003). The power of the media: A handbook for peacebuilders. Retrieved from http://www.xs4all.nl/ \%7Econflic1/Media_book_nieuw/a_b_contents.htm

Lehmann, I. (1999). Peacekeeping and public information: Caught in the crossfire. London: Frank Cass.

Kempf, W. (Ed.). (2008). The peace journalism controversy. Berlin: Regener.

Livingston, S. L. (2011). Africa's evolving infosystems: A pathway to security and stability (Research Paper, no. 2). Boulder, Colorado: Africa Center for Strategic Studies.

Price, M., \& Krug, P. (2002). A module for media intervention. In M. Price \& M. Thompson (Eds.), Forging peace: Intervention, human rights, and the management of media space (pp. 148-176). Bloomington: Indiana University Press.

Price, M., \& Thompson, M. (Eds.) (2002). Forging peace: Intervention, human rights and the management of media space. Bloomington: Indiana University Press.

Radio Netherlands. (2004). Peace radio: Burundi. Retrieved from http://www.rnw.nl/realradio/dossiers/ 
html/burundi-p.html

Search for Common Ground. (2002). Macedonia: Nashe Maalo. Retrieved from www.sfcg.org

Stauffacher, D., Weekes, B., Gasser, U., Maclay, C., \& Best, M. (Eds.). (2011). Peacebuilding in the infor- mation age. Sifting hype from reality. Geneva: ICT4Peace Foundation.

Wolfsfeld, G. (2004). Media and the path to peace. Cambridge: Cambridge University Press.

\section{About the Author}

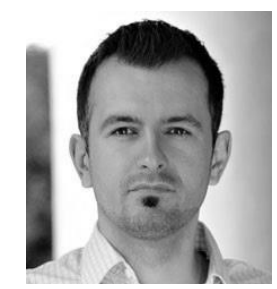

\section{Dr. Vladimir Bratic}

Vladimir Bratic is associate professor of media and communications at Hollins University in the USA. $\mathrm{He}$ is the author of several journal articles, professional publications and reports on the role of the media in conflict and peace. Prior to coming to the United States, Dr. Bratic graduated from the Faculty of Pedagogy and Philosophy at the Palacky University, Czech Republic. He obtained a Master's degree in International Relations and a PhD in Mass Communication from Ohio University. 